\title{
FOCUS 原子力学会の活動
}

\section{「原子力安全」調査専門委員会を設置}

原子力学会は福島第一原子力発電所における事故の原因や現象，影響を把握するために，「原子力安全」調査専門委員 会を設けました。同委員会は，下記のことがらを検討する予定です。

・地震・津波の想定の妥当性

・地震の影響の把握

・津波の影響の把握

・電源系統の故障/復旧の実態把握

- 冷却系統の故障/復旧の実態把握

- 事故進展 (燃料損傷)の把握

・バウンダリーの健全性の実態把握

・ FP 挙動の把握

・従事者の被ばく

・避難者・屋内退避者の被ばく

・遠隔地の被ばく
・環境污染の評価

・アクシデントマネージメントの評価

・防災対策の評価

・情報発信の評価

- 社会的影響の評価

- 安全研究への反映事項

・規制への反映事項

・失われた信頼をどう取り戻すか

・人材育成，特に安全分野，研究開発との関係

·国際連携, 協働

・原子力学会が果たすべき役割

関連リンク 皆様が関心を持たれる情報を発信している組織の URL をご紹介します。

\author{
東京電力株式会社 \\ http : //www.tepco.co.jp/index-j.html
}

原子力安全・保安院

http ://www.nisa.meti.go.jp/

首相官邸のモニタリングデータ

http : / / www. kantei. go. jp. cache. yimg. jp / saigai / monitoring/index.html

\section{放射線医学総合研究所}

http : //www.nirs.go.jp/index.shtml

http : //www.nirs.go.jp/information/info.php?i 3

http : //www.nirs.go.jp/information/info.php?i 4

\section{日本技術士会原子力・放射線部会 (国や自治体等が公表} している環境放射線のモニタリング情報のリンク集）

http ://www.engineer.or.jp/dept/nucrad/open/index. html

日本原子力研究開発機構 (対応の経過や放射線量の推移 等を揭載)

http : //www.jaea.go.jp/jishin/page.html

東京大学環境モニタリング情報

http : //www 2.u-tokyo.ac.jp/erc/index.html
九州大学エネルギー量子工学部門 (放射線関連の情報) http : //www.qpn.kyushu-u.ac.jp/message/index.html

日本原子力産業協会 (事故情報)

http : //www.jaif.or.jp/ja/news/news_detail.php 同 ·英文

http : //www.jaif.or.jp/english/index.php

$\mathrm{NRC}$ の日本関連情報

http : //www.nrc.gov/japan/japan-info.html

サイエンス・メディア・センタ（原子力に関する $\mathrm{Q} \& \mathrm{~A}$ )

http : //smc-japan.sakura.ne.jp/?p=752

日本放射線技師会(関連リンクのリスト掲載)

http : //www.jart.jp/

電気事業連合会 (原発・放射線関係のリンク)

http : //www.fepc.or.jp/

東京都市大学 - 早稲田大学共同原子力専攻岡研究室 (関 連情報， $\mathrm{Q} \& \mathrm{~A}$ 等を掲載)

http : //www.f.waseda.jp/okay/

同 ·英文

http : //www.f.waseda.jp/okay/index_en.html

日本保健物理学会 (暮らしの放射線 Q\&A)

http : //radi-info.com/ 